\title{
Phycological biodiversity at the Natural Park Serra da Enciña da Lastra (Ourense, Spain)
}

\author{
M. del Carmen López Rodríguez ${ }^{1 *}$, Manel Leira Campos $^{2} \&$ Rafael Carballeira Coego $^{1}$ \\ ${ }^{1}$ Departamento de Botánica. Facultad de Biologia. Universidad de Santiago de Compostela, \\ Rúa Lope Gómez de Marzoa, s.n. Campus Vida. 15782 Santiago de Compostela, Spain \\ mdelcarmen.lopez.rodriguez@usc.es, rafael.carballeira@gmail.com \\ ${ }^{2}$ Facultad de Ciencias, Universidad de Lisboa, Campo Grande, 1749-016 Lisboa, Portugal \\ mleira@fc.ul.pt
}

\begin{abstract}
López Rodríguez, M.C., Leira Campos, M. \& Carballeira Coego, R. 2016. Phycological biodiversity at the Natural Park Serra da Enciña da Lastra (Ourense, Spain). Anales Jard. Bot. Madrid 73(1): e036.

We have studied the phycological diversity at the Natural Park of Serra da Enciña da Lastra (Ourense, Spain) and present here the algae checklist of the Galir river, the only permanent fluvial course in the area. This geographical zone is a $\mathrm{SCl}$ (Site of Community Importance) and is located within an European Nature Reserve belonging to the "Nature 2000" network. Despite its environmental importance there is no previous phycological survey to this study. We collected samples in three points along the river, and measured physical and chemical water parameters ( $\mathrm{pH}$, conductivity, temperature, and dissolved oxygen). The checklist includes 88 taxa: 6 Cyanophyta, 4 Rhodophyta, 60 Heterokontophyta (58 Bacillariophyceae, 2 Xantophyceae), 1 Dinophyta, 2 Euglenophyta, and 15 Chlorophyta. Within the Rhodophyta we highlight the presence of Lemanea condensata, as a new record to the Iberian Peninsula. In addition, we have identified 8 new records for Galicia and 14 for Ourense.
\end{abstract}

Keywords: Bacillariophyceae, Chlorophyta, Cyanophyta, Euglenophyta, freshwater algae, Lemanea condensata, Ourense, Rhodophyta, Serra Enciña da Lastra, Spain, Xanthophyceae.

\section{INTRODUCTION}

The Natural Park Serra da Enciña da Lastra occupies 3,151.67 hectares in Rubiá (Ourense, Spain), in the southeast of Galicia, right on the border with the Bierzo (Leon) (Fig. 1). The Natural Park has an extraordinary uniqueness and a high proportion of endemic and rare species, hence its great biological interest primarily because of two features: first, the existence of limestone outcrops, rare in the rest of Galicia, and on the other, the low rainfall and strong Mediterranean climate. The only permanent freshwater course in the Sierra is the river Galir. The Peñarrubia reservoir, which collects the waters from the Sil river, is also included within the Park boundaries.

There are already several papers on the freshwater phycological flora in Galicia, among which are those of Bescansa $(1907,1908)$ on Conjugates of Ourense and Pontevedra, and Gamundi (1911) on diatoms. Allorge (1928) and Allorge \& Allorge (1930) studied the flora of all four provinces of Galicia, and Margalef (1956) included algal communities in mountain streams in various parts of the provinces of Ourense, Pontevedra, León and Zamora. Varela (1976, 1982) and Varela \& al. (1991) study diatoms in the surroundings of Santiago de Compostela, and Ector (1992) in rivers

\section{Resumen}

López Rodríguez, M.C., Leira Campos, M. \& Carballeira Coego, R. 2016. Diversidad ficológica del Parque Natural Serra da Enciña da Lastra (Orense, España). Anales Jard. Bot. Madrid 73(1): e036.

Se ha estudiado la diversidad ficológica del río Galir, el único curso fluvial permanente del Parque Natural Serra da Enciña da Lastra (Orense, España). Es un Lugar de Importancia Comunitaria (LIC) incluido en la red de espacios naturales "Natura 2000". A pesar de su importancia ambiental, no hay ningún estudio ficológico previo al presente. El catálogo de la flora ficológica incluye táxones recogidos de tres puntos del río y se han tenido en cuenta algunos parámetros físicoquímicos del agua: $\mathrm{pH}$, conductividad, temperatura y oxígeno disuelto. El catálogo florístico incluye 88 táxones: 6 Cyanophyta, 4 Rhodophyta, 60 Heterokontophyta (58 Bacillariophyceae y 2 Xantophyceae), 1 Dinophyta, 2 Euglenophyta y 15 Chlorophyta. Entre las Rhodophyta destaca Lemanea condensata, por ser nueva cita para la Península Ibérica. Además, se han encontrado 8 nuevas citas para Galicia y 14 para la provincia de Orense.

Palabras clave: algas dulceacuícolas, Bacillariophyceae, Chlorophyta, Cyanophyta, España, Euglenophyta, Lemanea condensata, Orense, Rhodophyta, sierra de la Encina de la Lastra, Xanthophyceae.

of A Coruña, Lugo, and Pontevedra. More recently, De la Peña (2003) has worked in rivers of A Coruña. A few studies have focused on the algae flora in hot springs (Noguerol 1984, 1990, 1991), and Cyanophyta (Temes, 1999; Temes \& Noguerol, 2000, 2002). Studies on mountain areas include Noguerol (1993) who provides data of the SE mountains, Penalta \& López Rodríguez (2007) and López Rodríguez \& Penalta (2007) on rivers of the Massif Central.

Despite the uniqueness of the Serra da Lastra Encina within the NW of the Iberian Peninsula, no studies of its phycological flora have been carried out, leading to an underestimation of the algae's regional richness in Spain. The aim of this work is the study of the phycological flora of water courses in this Natural Park in order to deliver a more complete account of the biodiversity in this Site of Community Importance (SCI) of the European natural reserve "Natura 2000".

The Natural Park Serra da Enciña da Lastra (Fig. 1) consists of a karstic massif which runs in direction NW-SE from the Oulego cliffs (960 masl), towards the Sil river valley which crosses through the limestone system. The Covas strait, territory located to river Sil West and the Páramo mountains, make up the total area of the Sierra da Lastra. 


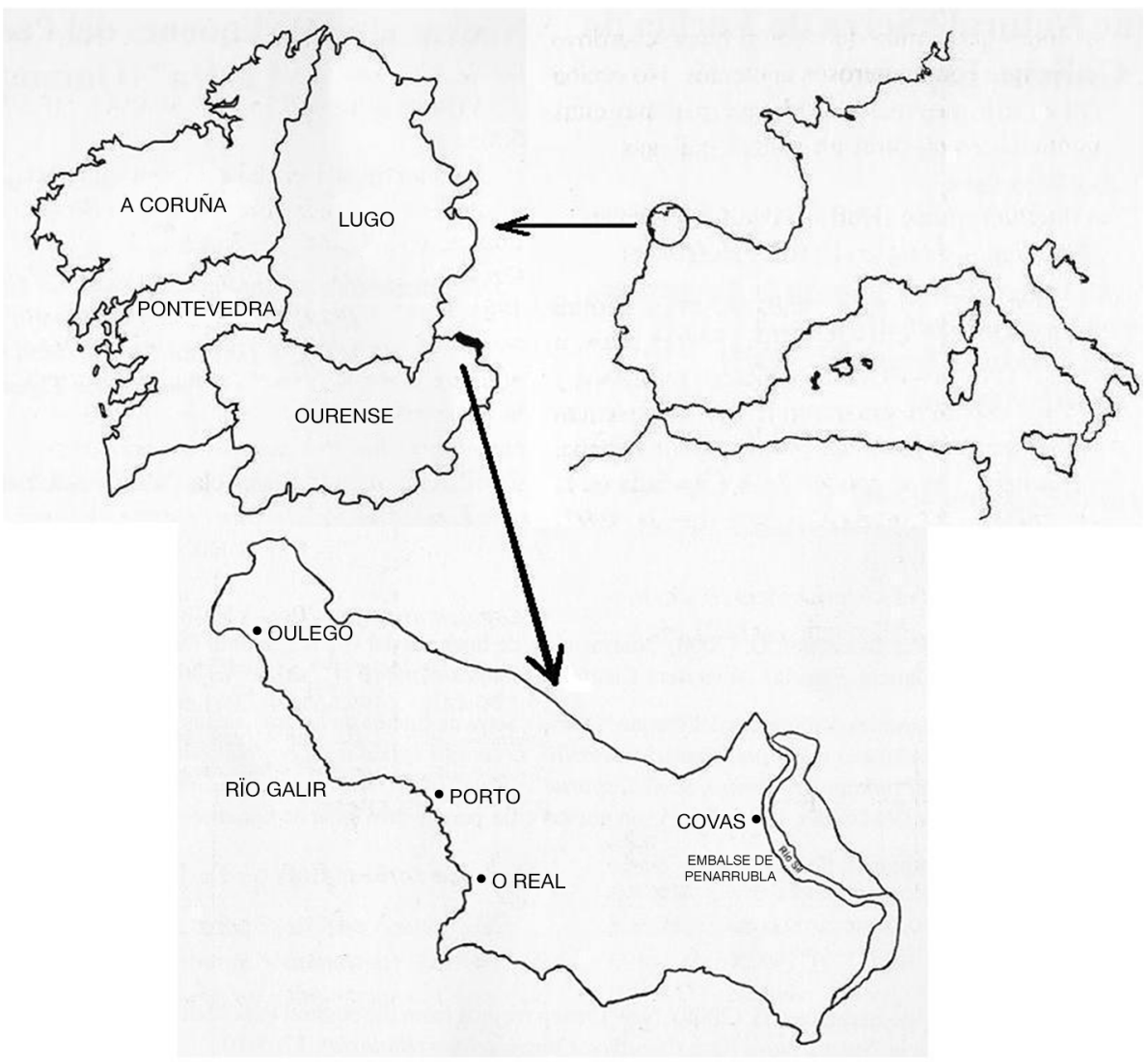

Fig. 1. Map of Europe, Galicia and Serra da Enciña da Lastra with sample sites in Galir river.

This Sierra comprises an important network of caves and chasms that are somewhat unusual in Galicia, and represents the best example of karst morphology in Galician land. The limestone substrates represent only $0.52 \%$ of Galician land, and Sierra da Enciña da Lastra is the most extensive zone.

There are no weather stations within the Park, but the data recorded by the three nearest stations show a temperate Mediterranean climate with a summer drought period lasting approximately three months (Carballeira \& al., 1983). These conditions allow the growth of holm oak and other Mediterranean taxa, being the only known area for thyme in Galicia.

\section{MATERIAL AND METHODS}

Sampling was carried out between 2006 and 2007 at four sites in the Galir river (Table 1). The samples were collected by scraping stones positioned in most cases in the middle of the river, and using a phytoplankton net at the reservoir. The material, pre-labeled, was kept in a cool-box until it reached the laboratory, where it was fixed with $4 \%$ formaldehyde. Samples for diatom analysis were treated with hot hydrogen peroxide at $3 \%$, for $6-8$ hours, they were then washed several times with distilled water and mounted in preparations with Naphrax (Kelly, 1998; Cen, 2003, 2004).

Measurements of some water physicochemical parameters were taken in situ (temperature, $\mathrm{pH}$, conductivity, and dissolved oxygen), using a pH-meter HI-9024 / C, conductivity with probe HI-76302 C / Malt. HI-9033 and HI-9143 oximeter.

Algae were identified using standard literature for Cyanophyta (Anagnostidis \& Komárek, 1985, 1988, 1990; Komárek \& Anagnostidis, 1999, 2005), Rhodophyta (Kumano, 2002; Eloranta \& Kwandrans, 2007, 2012; Eloranta \& al., 2011), Euglenophyta and Dinophyta (John \& al., 2002), Xantophyceae (Ettl, 1978), and Bacillariophyceae (Krammer \& Lange-Bertalot, 1986, 1988, 1991a, 1991b; Lange-Bertalot \& Krammer, 1989; Reichardt, 1999; LangeBertalot, 1996, 1999, 2001, 2011; Krammer, 1997a, 1997b, 2000, 2002, 2003). For Chlorophyta we followed the criteria of Förster (1982), Komárek \& Fott (1983), Ettl \& Gärnert (1988), Lokhorst (1999), and John \& al. (2002). For authors and abbreviations we used Brummitt \& Powell (1992) and Guiry \& Guiry (2016).

\section{RESULTS}

This floristic catalogue consists of 88 taxa: 6 Cyanophyta, 4 Rhodophyta, and 60 Heterokontophyta: 58 Bacillariophyceae and 2 Xantophyceae, one Dinophyta, 2 Euglenophyta, and 15 Chlorophyta. Within the catalogue there are new records for Ourense, Galicia, and the Iberian Peninsula. New cites for Ourense are indicated with one asterisk $(*)$, two $(* *)$ for Galicia, and three $(* * *)$ for the Iberian Peninsula. 
Table 1. Locations and physicochemical variables.

\begin{tabular}{|c|c|c|c|c|c|c|c|}
\hline Sampling point & $\begin{array}{c}\text { Altitude } \\
\mathrm{m}\end{array}$ & Coordinate & Data & $\begin{array}{c}\text { Temperature } \\
\text { water }{ }^{\circ} \mathrm{C}\end{array}$ & $\mathrm{pH}$ & $\begin{array}{c}\text { Conductivity } \\
\mu \mathrm{S} / \mathrm{cm}\end{array}$ & Oxygen (mg/1) \\
\hline \multirow{3}{*}{ Peñarrubia } & & $6^{\circ} 49^{\prime} 50^{\prime \prime} \mathrm{W}$ & 21/07/06 & 23,4 & 8,1 & 232,0 & 8,9 \\
\hline & & & 17/11/06 & 11,9 & 7,7 & 173,6 & 10,0 \\
\hline & & & 08/05/07 & 16,9 & 7,9 & 168,1 & 9,9 \\
\hline \multirow[t]{3}{*}{ O Real } & 442 & $42^{\circ} 28^{\prime} 20^{\prime \prime} \mathrm{N}$ & 29/03/06 & 9,7 & 7,3 & 83,1 & 11,3 \\
\hline & & & 17/11/06 & 10,7 & 7,5 & 103,5 & 11,0 \\
\hline & & & 08/05/07 & 12,8 & 7,7 & 96,0 & 11,2 \\
\hline \multirow[t]{3}{*}{ Porto } & 459 & $42^{\circ} 28^{\prime} 59^{\prime \prime} \mathrm{N}$ & 29/03/06 & & & & \\
\hline & & $6^{\circ} 53^{\prime} 46^{\prime \prime} \mathrm{W}$ & $21 / 07 / 06$ & 17,6 & 7,3 & 100,3 & 8,6 \\
\hline & & & 17/11/06 & 10,8 & 7,5 & 89,8 & 11,1 \\
\hline \multirow{2}{*}{ Oulego } & & & 17/11/06 & 11,2 & 7,6 & 79,3 & 10,9 \\
\hline & & & 08/05/07 & 12,7 & 7,4 & 84,2 & 10,8 \\
\hline
\end{tabular}

\section{CYANOPHYTA}

Lyngbya martensiana Menegh. ex Gomont Nostoc sphaericum Vaucher ex Bornet \& Flahault Oscillatoria tenuis C. Agardh ex Gomont Phormidium autumnale Gomont Phormidium retzii Kütz. ex Gomont Planktothrix agardhii (Gomont) Anagn. \& Komárek**

\section{RHODOPHYTA}

Audouinella sp.

Hildenbrandia rivularis (Liebm.) J. Agardh

Lemanea condensata Israelson****

Lemanea fluviatilis (L.) C. Agardh

\section{HETEROKONTOPHYTA}

\section{Bacillariophyceae}

Achnanthidium minutissimum (Kütz.) Czarneki Achnanthidium subatomoides (Hust.) O. Monnier, LangeBert. \& Ector*

Achnanthidium subatomus (Hust.) Lange-Bert. * Achnanthidium subbudsonis (Hust.) H. Kobayasi * Adlafia bryophila (J.B. Petersen) Gerd Moser, Lange-Bert. \& Metzeltin

Amphora indistincta Levkov **

Cocconeis euglypta Ehrenb.

Cocconeis placentula Ehrenb.

Cocconeis pseudolineata Geitler (Lange-Bert.) **

Cyclotella meneghiniana Kütz.

Cymatopleura solea (Bréb.) W. Sm. *

Diadesmis perpusilla (Grunow) D.G. Mann

Diatoma mesodon (Ehrenb.) Kütz.
Diploneis ovalis (Hilse) Cleve *

Diploneis petersenii Hust.

Encyonema minutum (Hilse) D.G. Mann

Epithemia turgida (Ehrenb.) Kütz. *

Eunotia bilunaris (Ehrenb.) Schaarschm.

Eunotia exigua (Bréb. ex Kütz.) Rabenh.

Eunotia minor (Kütz.) Grunow

Eunotia praerupta Ehrenb.

Fragilaria gracilis Østrup **

Fragilaria rumpens (Kütz.) G.W.F. Carlson *

Fragilaria vaucheriae (Kütz.) J.B. Petersen

Frustulia vulgaris (Thwaites) De Toni

Gomphonema acuminatum Ehrenb.

Gomphonema gracile Ehrenb.

Gomphonema minutum (C. Agardh) C. Agardh *

Gomphonema parvulum (Kütz.) Kütz.

Gomphonema pumilum var. rigidum E. Reichardt \&

Lange-Bert. $* *$

Gomphonema rhombicum Fricke

Hannaea arcus (Ehrenb.) R.M. Patrick

Hantzschia amphioxys (Ehrengb.) Grunow

Karayevia oblongella (Østrup) Aboal

Melosira varians C. Agardh

Meridion circulare var. constrictum (Ralfs) Van Heurck

Navicula cryptocephala Kütz.

Navicula cryptotenella Lange-Bert. *

Navicula gregaria Donkin

Navicula minima Grunow

Navicula radiosa Kütz.

Navicula rbyncocephala Kütz.

Nitzschia dissipata (Kütz.) Rabenh.

Nitzschia linearis W. Sm.

Nitzschia palea (Kütz.) W. Sm.

Nupela lapidosa (Krasske) Lange-Bert.

Pinnularia anglica Krammer * 
Placoneis cf. anglica (Ralfs) E.J. Cox

Planothidium lanceolatum (Bréb. ex Kütz.) Lange Bert.

Psammothidium marginulatum (Grunow) Bukhtiyarova \& Round **

Reimeria sinuata (W. Greg.) Kociolek \& Stoermer

Rhoicosphenia abbreviata (C. Agardh) Lange-Bert. *

Rhopalodia gibba (Ehrengb.) O. Müll. *

Stauroneis anceps Ehrengb.

Surirella linearis W. Sm.

Tabellaria floculosa (Roth) Kütz.

Ulnaria biceps (Kütz.) Compère *

Ulnaria ulna (Nitzsch) Compère

\section{Xantophyceae}

Vaucheria prona T.A.Chr. *

Vaucheria sessilis (Vaucher) D.C. *

\section{EUGLENOPHYTA}

Lepocinclis ovum (Ehrenb.) Lemmerm. **

Trachelomonas hispida var. coronata Lemmerm.

\section{CHLOROPHYTA}

Cladophora glomerata (L.) Kütz. *

Closterium acerosum Ehrenb. ex Ralfs

Closterium ehrenbergii Menegh. ex Ralfs

Closterium littorale F. Gay

Closterium lunula Ehrenb. \& Hemprich ex Ralfs

Closterium moniliferum Ehrenb. ex Ralfs

Closterium turgidum Ehrenb. ex Ralfs

Cosmarium sp.

Klebsormidium flaccidum (Kütz.) P.C. Silva \& al.

Microspora amoena (Kütz.) Rabenh.

Microspora amoena var. gracilis (Wille) De Toni ***

Oedogonium sp.

Spirogyra sp.

Staurastrum muticum Bréb. ex Ralfs *

Ulothrix sp.

\section{Peridinium sp.}

(a)

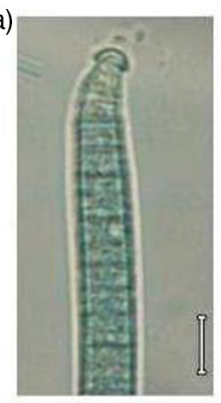

(b)

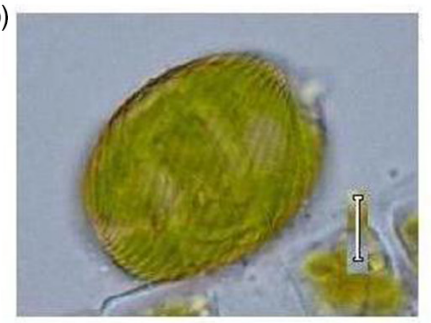

(c)

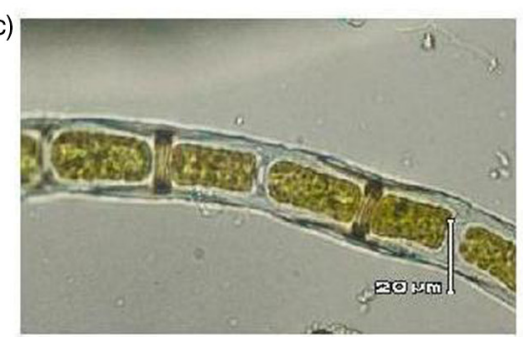

(d)

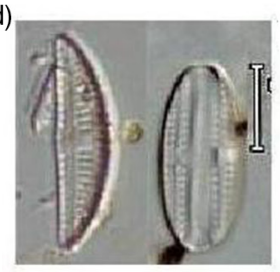

(h)

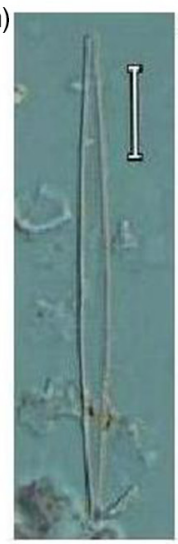

(e)

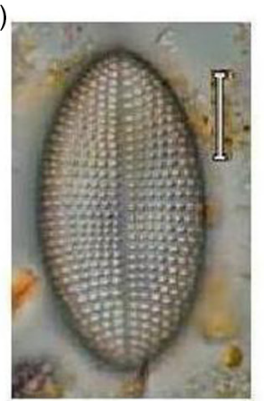

(f)

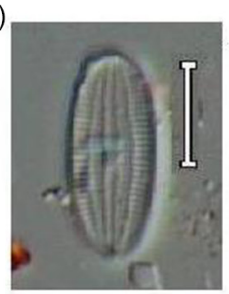

(g)

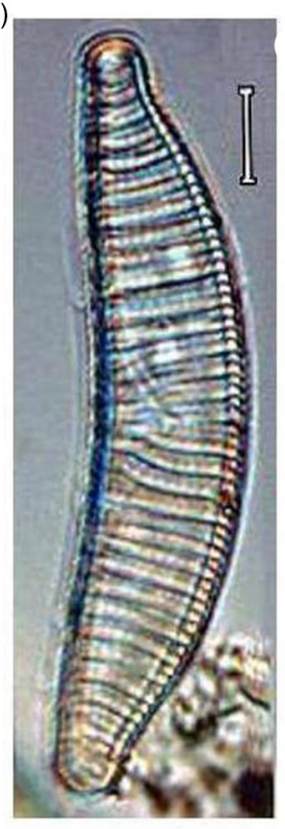

Fig 2. Cyanophyta: a, Plantothrix agardhii. Euglenophyta: b, Lepocinclis ovum. Chlorophyta: c, Microspora amoena var. gracilis. Heterokontophyta (Bacillariophyceae): d, Amphora indistincta; e, Cocconeis pseudolineata; f, Diploneis peterseni; g, Epithemia turgida; h, Fragilaria gracilis; i, Gomphonema pumilum var. rigidum; j, Placoneis cf. anglica. Scale $6 \mu \mathrm{m}$, except for Epithemia turgida, $9 \mu \mathrm{m}$. 


\section{DESCRIPTION OF SOME RELEVANT SPECIES}

Planktothrix agardhii (Gomont) Anagnostidis \& Komárek (Fig. 2a)

Oscillatoria agardhii Gomont

[Cyanophyta; Oscillatoriales; Phormidiaceae]

Trichomes solitary, immotile, blue-green colour, freefloating. Cells $3 \mu \mathrm{m}$ long, up to $6 \mu \mathrm{m}$ wide. Apical cells somewhat curved and convex with caliptra.

Distribution: It is widely distributed in temperate zones. New record to Galicia.

\section{Lemanea condensata Israelson (Fig. 3)}

[Rhodophyta; Florideophyceae; Batrachospermales; Lemaneaceae]

Rhodophyte with cylindrical stem (Fig. 3 a) in the form of cartilaginous unbranched tufts, somewhat curved, gradually narrowing towards the base, lacking the typical constriction of other species such as Lemanea fluviatilis. Spermatangial prominent papillae more or less regularly distributed in number up to 3 per node (Fig. 3 b, d). Chantransia phase (Fig. 3 c) is represented by irregularly branched filaments without terminal hairs.

The thallus of our specimens measured $2.4 \mathrm{~cm}$ in length, although Eloranta \& al. (2011) suggest that they may reach up to $3 \mathrm{~cm}$. Internodes length of $480-620 \mu \mathrm{m}$ and $100-250 \mu \mathrm{m}$ wide. Nodes width including spermatangial papillae varies from 250-375 $\mu \mathrm{m}$, these measurements are slightly higher $(220-350 \mu \mathrm{m})$ than those described by Israelson (1942), Kumano (2002), Eloranta \& Kwandrans (2007), and Eloranta \& al. (2011).

Lemanea borealis resembles $L$. condensata regarding the small size of the thallus, although the former can reach $5 \mathrm{~cm}$, but differs from $L$. condensata in that 2 to 5 spermatangial papillae are present in spots that do not protrude into the thallus.

It is possible that our specimens correspond to L. hispanica, described and identified for the first time in 1928 by Budde (1929) in the Sierra de Guadarrama (La Granja, Segovia, Spain) in a mountain stream with a strong current on granite stones. The size of these specimens $(1-2 \mathrm{~cm})$, the unthinned base, and the presence of two spermatangial papillae, are characteristics that agree with those observed in our specimens in the Galir river, so it might be considered the same species. However Israelson (1942) indicates that due to the lack of proper diagnosis a closer comparison between $L$. condensata and L. bispanica is not possible.

Distribution: It is restricted to the northern European countries: Sweden, Finland, and Norway (Eloranta \& al., 2011).

\section{Amphora indistincta Levkov (Fig. 2 d)}

[Heterokontophyta; Bacillarophyceae; Thalassiophysales; Catenulaceae]

Cells $13 \mu \mathrm{m}$ long, $5 \mu \mathrm{m}$ wide. Ventral grooves $13 / 10 \mu \mathrm{m}$ converging radially outward. Dorsal striae $12 / 10 \mu \mathrm{m}$. Dorsal area present. Dorsal punctae visible. Valves semilanceolate, with the ventral margin nearly straight or slightly concave, but convex dorsal margin. Ends rounded, narrow and slightly obtuse, directed forward. Raphe branches slightly curved or straight.
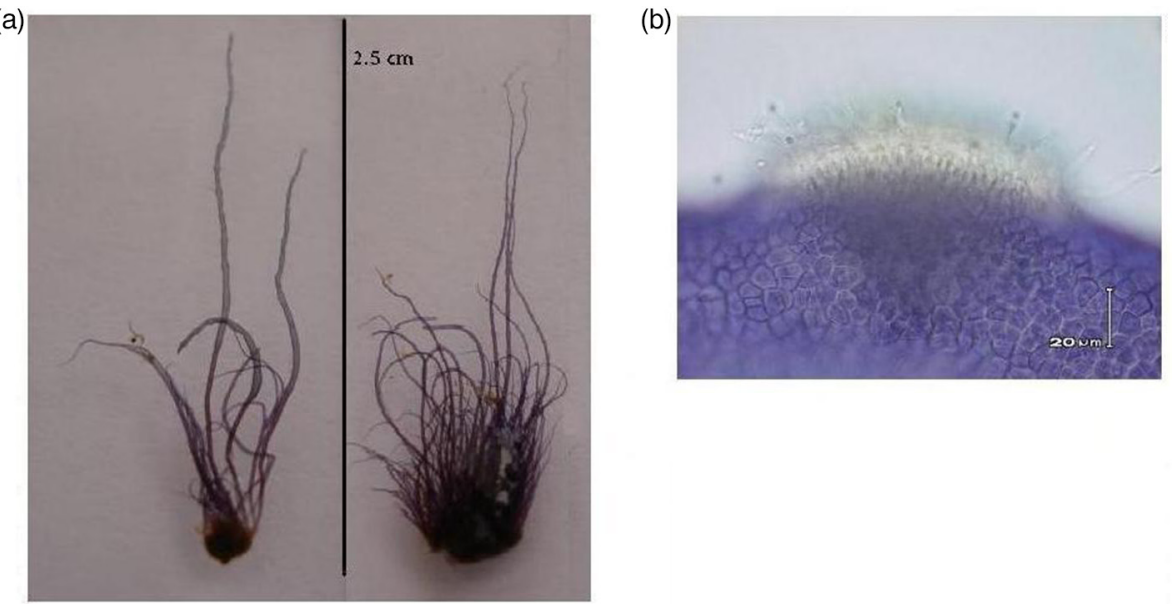

(d)

(c)

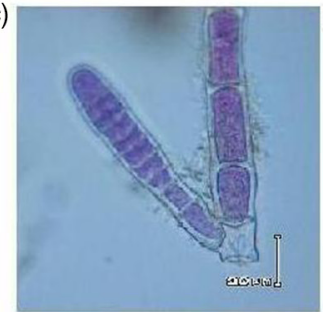

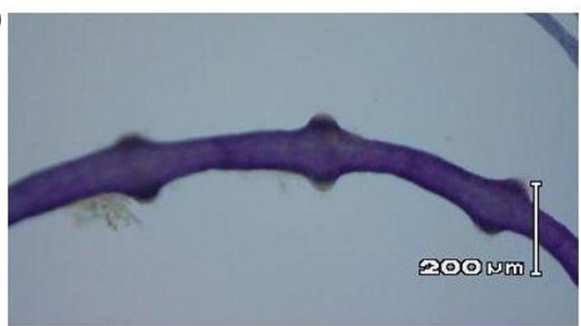

Fig 3. Rhodophyta: Lemanea condensata: $a$, habit; b, spermatangial papillae; $c$, Chantrasia; $d$, thallus with two spermatangial papillae. 
Distribution: Widely distributed in Spain. New record in Galicia.

Cocconeis pseudolineata Geitler (Lange-Bertalot) (Fig. 2 e) Cocconeis placentula var. pseudolineata Geitler

[Heterokontophyta; Bacillarophyceae; Achnanthales; Cocconeidaceae]

Cells $17-20 \mu \mathrm{m}$ long, 9-12 $\mu \mathrm{m}$ wide. Valve shape elliptic or elliptical-linear. Raphe with a narrow linear axial area and a small circular central area. Striae very thin, almost parallel in the centre and radially towards the poles. The rapheless valve shows striae with larger areolae, slightly elongated and arranged in more or less regular rows.

Distribution: Widely distributed in Spain.

Diploneis peterseni Hustedt (Fig. $2 \mathrm{f}$ )

[Heterokontophyta; Bacillarophyceae; Naviculales; Diploneidaceae]

Cells $12 \mu \mathrm{m}$ long, $4.8 \mu \mathrm{m}$ wide. Valves broadly elliptic to weakly elliptical, but almost strictly linear. Broadly rounded ends. Striae radial with delicate appearance. The points in the striae can not be resolved under light microscopy.

Distribution: Only one citation in Andorra and in Galicia. It was found in Ourense province by Antelo (1991) at the Barbaña river.

Epithemia turgida (Ehrenberg) Kützing (Fig. 2 g)

Navicula turgida Ehrenberg

[Heterokontophyta; Bacillarophyceae; Rhopalodiales; Rhopalodiaceae]

Cells $67.5 \mu \mathrm{m}$ long, $15.5-16 \mu \mathrm{m}$ wide. Striae 8-10/10 $\mu \mathrm{m}$; ribs $4-5 / 10 \mu \mathrm{m} ; 2-3$ striae between ribs. Ventral margin slightly concave. Raphe channel placed against the ventral margin at the distal ends of the valve and arched towards the back in the middle of the valve, reaching nearly half the distance to the posterior margin.

Distribution: Widely distributed in Spain.

Fragilaria gracilis Oestrup (Fig. 2 h)

[Heterokontophyta; Bacillarophyceae; Fragilariales; Fragilariaceae]

Cells $32 \mu \mathrm{m}$ long, $1.8 \mu \mathrm{m}$ wide. Striae $19-23$ striae in $10 \mu \mathrm{m}$. Valves nearly linear with subcapitated or gradually attenuated apices. Striae shortened, evident in the margin and dotted near the axial zone.

Distribution: Although it has been found repeatedly in Portugal (Beira Litoral; Gil, 1988; Gil \& al., 1991; Almeida, 1998;), its presence in Spain is uncertain. It has recently been cited in the catalogue of phytoplankton quality elements for the assessment of the ecological status (MAAM, 2012), but it does not provide distributional data.

Gomphonema pumilum var. rigidum Reichardt \& LangeBertalot (Fig. 2 i)

Gomphonema intricatum var. pumila Cleve-Euler

[Heterokontophyta; Bacillarophyceae; Cymbellales;

Gomphonemataceae]
Cells $18.4 \mu \mathrm{m}$ long, $3.6 \mu \mathrm{m}$ wide. Striae 13-14/10 $\mu \mathrm{m}$, slightly radial, hardly bent. Valves linear-lanceolate with rounded ends. Head pole moderately wider than the foot pole. The axial area is presented in a variable form, from linear to lanceolate. The central area wide, rectangular-shaped in transverse direction, ending in a short ridge on each side. Raphe quite simple, filiform. The stigma near the central node is clearly separated from the central striae.

Distribution: Mainly in the western part of the Iberian Peninsula.

Placoneis cf. anglica (Ralfs) Cox (Fig. 2 j)

Navicula anglica Ralfs

[Heterokontophyta; Bacillarophyceae; Cymbellales; Cymbellaceae]

Cells $22 \mu \mathrm{m}$ long, $6 \mu \mathrm{m}$ wide. Valves elliptical-lanceolate, the margins convex, with apices rostrate and elongated. Axial area lanceolate, narrow at the apex and extending towards the centre, where it expands in the transverse direction. Raphe straight and filiform with rounded proximal end and the distal deflected in the opposite direction. Striae slightly curved and radial arrangement along the length of the valve.

Distribution: Common in the Iberian Peninsula but can be confused with P. elginensis, which is distinguished by its elliptical to linear-elliptical form.

Lepocinclis ovum (Ehrenberg) Lemmermann (Fig. 2 b) Euglena ovum Ehrenberg

[Euglenophyta; Euglenophyceae; Euglenales; Phacaceae]

Cells $24 \mu \mathrm{m}$ long, $18 \mu \mathrm{m}$ wide, ovoid, colour olive green. It presents a posterior end with a short blunt tail-piece and many discoidal chloroplasts. Pellicle covered with spiral striae.

Distribution: Probably cosmopolitan, living as planktonic.

Microspora amoena var. gracilis (Wille) De Toni (Fig. 2 c) Conferva amoena Kützing

[Chlorophyta; Chlorophyceae; Microsporales; Microsporaceae]

Uniseriate filaments, unbranched, with "H-shaped" segments in the cell wall. Cells 11.5-15 $\mu \mathrm{m}$ wide and $35 \mu \mathrm{m}$ long; wall 3,32 $\mu \mathrm{m}$ wide.

Distribution: Probably cosmopolitan, as it appears both in Europe and North America. New record to Galicia.

\section{DISCUSSION AND CONCLUSIONS}

For the first time, we provide data on the phycological flora of an uncommon area in Galicia due to the presence of limestone outcrops. In particular, Amphora indistincta, Coconeis pseudolineata, Ephitemia turgida, Gomphonema pumilum var. rigidum y Placoneis cf. anglica are alkaliphic and are present in this study; while they are absent or unimportant in the freshwater environment of the Galicia-Costa river basins.

In high and middle sections of Galician rivers, the diatom flora is characterized by circumneutral to acidophilic taxa, typical to waters with moderate to low electrolyte content. 
However, in Serra da Enciña da Lastra there are species which can only be found in Galicia in the lower river stretches with marine water influence. This is the case for Cocconeis spp., Ephitemia spp., and some fragilarioid taxa that are common in coastal lagoons (Delgado \& al., 2010; Carballeira, pers. comm.).

We highlight the presence of Lemanea condensata for being a new record in the Iberian Peninsula. Although this species is typical of northern areas and cited only in the nordic countries, it appears in Galician mountains, though not outstanding in altitude, such as Oulego Penedos of the Serra da da Lastra Encina, which does not exceed 960 meters. Another interesting record is Fragilaria gracilis, a common and frequent diatom in Portugal (Almeida, 1998; Gil, 1988; Gil \& al., 1991), and for which, although it has recently been cited in Spain (MAAM, 2012), we lack precise distributional data.

The location of the Serra da Enciña da Lastra, between the Mediterranean and Atlantic climate and its lithological peculiarities within the regional context, suggests that we might expected a significant increase in the number of species in future studies, similar to the results obtained, in terms of the singularity and diversity of vascular plants (Gimenez de Azcárate \& Amigo, 1996).

\section{ACKNOWLEDGEMENTS}

This study was funded by the Consellería de Medio Ambiente e Desenvolvemento Sostible de la Xunta de Galicia (PGIDIT05RFO20002PR).

\section{REFERENCES}

Aboal, M., Alvárez Cobelas, M., J. Cambra, J. \& Ector, L. 2003: Floristic list of the non marine diatoms (Bacillariophyceae) of Iberian Peninsula, Balearic Islands and Canary Islands. Update taxonomy and bibliography. In: Witkowski, A. (ed), Diatom Monographs 4: 1-639. Berlin, J. Cramer.

Allorge, P. 1928. Note préliminaire sur la flore des Algues d'eau douce de la Galice. (Euchlorophycées, Conjuguées et Hétérocontes). Boletín de la Real Sociedad Española de Historia Natural 28: 469-476.

Allorge, V. \& Allorge, P. 1930. Hétérocontes, Euchlorophycées et Conjuguées de Galicie. Matériaux pour la Flore des Algues d'eau douce de la Péninsule Ibérique I. Revue Algologique 5: 327-382.

Almeida, S.F.P. 1998. Utilizaçao das diatomaceas na avaliaçao da qualidade das agues doces. Tesis doctoral. Universidade de Aveiro.

Anagnostidis, K. \& Komárek, J. 1985. Modern approach to the classification system of Cyanophytes. I. Introduction. Algological Studies 38/39: 291-302.

Anagnostidis, K. \& Komárek, J. 1988. Modern approach to the classification system of Cyanophytes. 3.- Oscillatoriales. Algological Studies 50/53: 327-472.

Anagnostidis, K. \& Komárek, J. 1990. Modern approach to the classification system of Cyanophytes. 5.- Stigonematales. Algological Studies 59: 1-73.

Antelo Cortizas, J.M. 1991. Calidad de las aguas de la cuenca del río Barbaña. Efecto del vertido del polígono industrial de San Ciprián das Viñas. Fundación Empresa-Universidad Gallega (FEUGA). 110 pp.

Bescansa Casares, f. 1907. Algunas "conjugadas" de la provincia de Orense. Boletín de la Real Sociedad Española de Historia Natural 7: 65-68.

Bescansa Casares, F. 1908. Conjugadas para la Flora de Galicia. Boletín de la Real Sociedad Española de Historia Natural 8: 234-238.

Brummitt, R.K. \& Powell, C.E. (eds.). 1992. Authors of plants names. A list of authors of scientific names of plants, with recommended standard forms of their names, including abbreviations. Royal Botanical Gardens, Kew.

Budde, H. 1929. Beitrag zur Algenflora der fließenden Gewässer Spaniens. Archiv für Hydrobiologie 20: 427-470.

Cambra Sánchez, J., Álvarez Cobelas, M. \& Aboal Sanjurjo, M. 1998. Lista florística y bibliográfica de los clorófitos (Chlorophyta) de la Peninsula Ibérica, Islas Baleares e Islas Canarias. In: García J. \& Rico, E. (eds.), Lista de la flora y fauna de las aguas continentales de la Península Ibérica, 14. Asociación Española de Limnología.
Carballeira, A., Devesa, C., Retuerto, R., Santillán E. \& Ucieda, F. 1983. Bioclimatología de Galicia. 391pp. A Coruña.

Cen. European Committee for Standardization. 2003. Water quality Guidance standard for the routine sampling and pre-treatment of benthic diatoms from rivers for water quality assessment. EN 13946:2003. Comité European de Normalisation, Geneva.

CEN. European Committee for Standardization. 2004. Water Quality Guidance Standard for the Identification, Enumeration and Interpretation of Benthic Diatom Samples from Running Waters. EN 14407:2004. Comité Européen de Normalisation, Geneva.

De la Peña, S. 2003. Biomonitorización de la calidad del agua de los ríos de la provincia de A Coruña usando diatomeas. Tesis de Licenciatura. 117 pp. Universidad de A Coruña. A Coruña.

Delgado, C., Pardo, I. \& García, L. 2010. A multimetric diatom index to assess the ecological status of coastal Galician rivers (NW Spain). Hydrobiologia 644: 371-384.

Dillard, G.E. 1989. Freshwater algae of the Southeastern United States. Part 1. Chlorophyceae: Volvocales, Tetrasporales and Chlorococcales (Section 1). In: Kies, L. \& Schnetter, R. (eds.), Bibliotheca Phycologica, 81. J. Cramer. Berlin.

Dillard, G.E. 1989. Freshwater algae of the Southeastern United States. Part 2. Chlorophyceae: Ulotricales, Microsporales, Cylindrocapsales, Sphaeropleales, Chaetophorales, Cladophorales, Schizogoniales, Siphonales and Oedogoniales. In: Kies, L. \& Schnetter, R. (eds.), Bibliotheca Phycologica, 83. J. Cramer. Berlin.

Dillard, G.E. 1999. Common Freshwater algae of the United States. An Illustrated Key to the Genera (Excluding the Diatoms). J. Cramer. Berlin.

Ector, L. 1992. Control de la calidad biológica de las aguas superficiales en la red de aforos de Galicia-costa mediante diatomeas bénticas. In: FEUGA. Fundación Empresa Universidad Gallega, Calidad del agua en las estaciones de aforo de los ríos de Galicia. Años bidrológicos 1989-90, 1990-91. pps.: 76-157. Xunta de Galicia, Santiago de Compostela.

Eloranta, P. \& Kwandrans, J. 2007. Freshwater Red Algae (Rhodophyta). Identification guide to European taxa, particularly to those in Finland. Norrlinia 15: 1-103.

Eloranta, P., Kwandrans, J. \& Kusel-Fetzmann, E. 2011. Rhodophyta and Phaeophyceae. In: Büdel, B. \& al. (eds.), Süßwasserflora von Mitteleuropa. Freshwater Flora of Central Europe, 7. Spektrum Akademischer Verlag, Heildelberg.

Ettl, H. 1978. Xanthophyceae. In: Ettl, H. \& al. (eds.), Süßwasserflora von Mitteleuropa. 1: 1-530. Gustav Fisher Verlag, Stuttgart.

Ettl, H. \& Gärnert, G. 1988. Chlorophyta II, Tetrasporales, Chlorococcales, Gloeodendrales. In: Ettl, H. \& al. (eds.), Süßwasserflora von Mitteleuropa. 10: 436. Gustav Fisher Verlag, Stuttgart.

Förster, K. 1982. Conjugatophyceae Zygnematales und Desmidiales (excl. Zygnemataceae). In: Huber-Pestalozzi, G. (ed.), Das Phytoplankton des Süßwassers, 8(1). Schweizerbart'sche Verlagsbuchhandlung. Stuttgart.

Gamundi, J. 1911. Diatomeas de Santiago de Compostela y alrededores. Boletín de la Real Sociedad Española de Historia Natural 11: 388-394.

Gil, M.C.P. (1988). Estudo ecológico das Diatomáceas dos Rios Águeda, Agadao, e Alfusqueiro. Ph. D. Thesis. Universidade de Aveiro.

Gil, M.C.P., Rino, J.A. \& Nicolau, F.C. 1991. Estudo ecológico das Diatomáceas dos Rios Águeda, Agadao, e Alfusqueiro. Diatomáceas potamoplanctonicas. Revista de Biologia da Universidade de Aveiro 4: 73-94.

Gimenez de Azcárate, J. \& Amigo, J. 1996. Inventario da flora vascular de afloramentos calizos de Galicia (Pteridophyta e Spermatophyta). Cadernos da Área de Ciencias Biolóxicas. Inventarios XII. Publicacións do Seminario de Estúdios Galegos, A Coruña.

Guiry, M.D. \& Guiry, G.M. 2016 AlgaeBase. World-wide electronic publication, National University of Ireland, Galway. http://www.algaebase. org (searched on 2nd June 2016).

Israelson, G. 1949. The freshwater Florideae of Sweden. Symbolae Botanicae Upsalienses 6: 1-135.

John, D.M., Whitton, B.A. \& Brook, A.J. 2002. The Freshwater Algal Flora of The British Isles. An Identification Guide to Freshwater and Terrestrial Algae. University Press, Cambridge.

Kelly, M.G., Cazaubon, A., Coring, E., Dell Uomo, A., Ector, L., Goldsmith, B., Guasch, H., Hürlimann, J., Jarlman, A., Kawecka, B., Kwandrans, J., Laugaste, R., Lindstrøm, E.A., Leitao, M., Marvan, P., Padisák, J., Pipp, E., Prygiel, J., Rott, E., Sabater, S., Dam, H. \& Vizinet, J. 1998. Recommendations for routine sampling of diatoms for water quality assessments in Europe. Journal of Applied Phycology 10: 215-224.

Komárek, J. \& K. Anagnostidis. 1999. Cyanophyta part I: Chroococcales. In: Ettl, H. \& al. (ed.), Süßwasserflora von Mitteleuropa, 19/1. Gustav Fisher, Jena. 
Komárek, J. \& K. Anagnostidis. 2005. Cyanophyta part 2: Oscillatoriales. In: Büdel, B.H. \& al. (ed.), Süßwasserflora von Mitteleuropa, 19/2. Gustav Fisher, Jena.

Komárek, J. \& B. Fott. 1983. Chlorophyceae (Grünalgen) Ordung Chlorococcales. In: Huber-Pestalozzi, G. (ed.), Das Phytoplankton des Süßwassers, 16 (7/1). Schweizerbart'sche Verlagsbuchhandlung. Stuttgart.

Krammer, K. 1997a. Die cymbelloiden Diatomeen. Eine Monographie der weltweit bekannten Taxa. Teil 1. Allgemeinen und Encyonema Part. Biblioteca Diatomologica, 36. J. Cramer. Berlin-Stuttgart.

Krammer, K. 1997b. Die cymbelloiden Diatomeen. Eine Monographie der weltweit bekannten Taxa. Teil 2. Encyonema Part., Encyonopsis und Cymbellopsis. Biblioteca Diatomologica, 37. J. Cramer. Berlin-Stuttgart.

Krammer, K. 2000. The genus Pinnularia. In: Lange Bertalot, H. (ed.), Diatoms of Europe, 1. ARG Gantner Verlag K.G.

Krammer, K. 2002. Cymbella. In: Lange Bertalot, H. (ed.), Diatoms of Europe. Diatoms of the European Inland Waters and Comparable babitats, 3. ARG Gantner Verlag K.G.

Krammer, K. 2003. Cymbopleura, Delicata, Navicymbula, Gomphocymbellopsis, Afrocymbella. In: Lange Bertalot, H. (ed.), Diatoms of Europe. Diatoms of the European Inland Waters and Comparable habitats, 4.. ARG Gantner Verlag K.G, Koenigstein.

Krammer, K. \& Lange-Bertalot, H. 1986. Bacillariophyceae. Naviculaceae. In: Ettl, H. \& al. (eds.), Die Süßwasserflora von Mitteleuropa, 2/1. G. Fisher Verlag. Stuttgart.

Krammer, K. \& Lange-Bertalot, H. 1988. Bacillariophyceae: Bacillariaceae, Epithemiaceae, Surirellaceae. In: Ettl, H. \& al. (eds.), Die Süßwasserflora von Mitteleuropa, 2/2. G. Fisher Verlag. Stuttgart.

Krammer, K. \& Lange-Bertalot, H. 1991a. Bacillariophyceae, 3 Teil: Centrales, Fragilariaceae, Eunotiaceae. In: Ettl, H. \& al. (eds.), Süßwasserflora von Mitteleuropa, 2/3. G. Fisher Verlag. Stuttgart.

Krammer, K. \& Lange-Bertalot, H. 1991b. Bacillariophyceae: Achnanthaceae, Kritische Ergäzungen zu Navicula (Lineolatae) und Gomphonema. In: Ettl, H. \& al. (eds.), Süßwasserflora von Mitteleuropa, 2/4. G. Fisher Verlag. Stuttgart.

Kumano, S. 2002. Freshwater red algae of the world. Biopress Limited. Bristol.

Lange-Bertalot, h. 2001. Navicula sensu stricto. 10 Genera separated from Navicula sensu lato Frustulia. In: Lange Bertalot, H. (ed.), Diatoms of Europe. Diatoms of the European Inland Waters and Comparable habitats, 2. ARG Gantner Verlag K.G.

Lange-Bertalot, H. \& Kramer, K. 1989. Achnanthes, eine Monographie der Gattung. Bibliotheca Diatomologica, 18. J. Cramer.

Lokhorst, G.M. 1999. Taxonomic study of the genus Microspora thuret (Chlorophyceae). An integrated field, culture and herbarium analysis. Algological Studies 93: 1-38.

López Rodríguez, M.C. \& Penalta Rodríguez, M. 2004. Aportación al conocimiento de la flora ficológica del Macizo Central Gallego (N.O. España). Anales de Biología de Murcia 26: 79-91.
MAAM (Ministerio de Agricultura, Alimentación y Medio Ambiente). 2012. Id-Tax. Catálogo y claves de identificación de organismos fitobentónicos utilizados como elementos de calidad en las redes de control del estado ecológico. Secretaría General Técnica. Centro de Publicaciones.

Margalef, R. 1948. Materiales para una flora de las algas del NE de España. II. Chrysophyceae, Heterocontae, Dinophyceae, Euglenineae. Collectanea Botanica 2(1): 100-130.

Margalef, R. 1955. Comunidades bióticas de las aguas dulces del noroeste de España. Publicaciones del Instituto de Biología Aplicada 21: 5-85.

Margalef, R. 1956. Algas de agua dulce del noroeste de España. Publicaciones del Instituto de Biología Aplicada 22: 43-152.

Noguerol, A. 1984. Cianofíceas termófilas de "As Burgas" (Ourense). Anales de Biología 2(secc. esp. 2): 127-133.

Noguerol, A. 1990. Estudio ficológico de la fuente termal de Torneiros (Lovios, Orense, España). Anales del Jardín Botánico de Madrid 47: 297-300.

Noguerol, A. 1991. Algas de fuentes termales del NW de España: Baños de Molgas y Caldas de Partovia. Acta Botánica Malacitana 16 (1): 27-30.

Noguerol, A. 1993. Algas dulceacuícolas de la Sierra de Invernadeiro (Orense, N.O. España). Nova Acta Científica Compostelana (Bioloxía) 4: 5-13.

Penalta Rodríguez, M. \& López Rodríguez, M.C. 2006: Contribution à la flore des diatomées épilithiques du Massif Central Galicien (Ourense, Espagne). Simbioses 14: 21-25.

Reichardt, E. 1999. Zur Revision der Gattung Gomphonema. Die Arten um G. affine/insigne, G. angustatum/micropus, G. acuminatum sowie gomphonemoide Diatomeen aus den Oberoligozän in Böhmen. In: LangeBertalot, H. (ed.), Iconographia Diatomologica 8. Koeltz Scientifc Books, Berlin.

Temes Casas, M. 1999. Estudio taxonómico y ecológico de las Cyanophyceae (Cianoprocariotas/ Cianobacterias) del río Lourido (A Coruña, N.O. España). Tesis de licenciatura. Universidade da Coruña.

Temes Casas, M. \& Noguerol, A. 2000. Estudio del género Microcoleus (Oscillatoriales, Cyanophyta) en el río Lourido (A Coruña, N.O. España). Portugaliae Acta Biologica 19: 71-79.

Temes Casas, M. \& Noguerol, A. 2002. Homoeothrix varians Geitler y Chamaesiphon confervicolus var. elongatus (Nordstedt) Kann (Cyanophyta), dos nuevas referencias para la Península Ibérica. Anales del Jardín Botánico de Madrid 59(2): 331-332.

Varela, M. 1976. Diatomeas de Santiago de Compostela y alrededores. Tesis de Licenciatura. Universidad de Santiago de Compostela.

Varela, M. 1982. Adiciones a la flora de diatomeas de agua dulce de Galicia. Collectanea Botanica 13(2): 977-985.

Varela, M., Rodríguez, B. \& Costas, E. 1991. Inventario de diatomeas de auga doce de Galicia (Bacillariophyceae). Cadernos da Area de Ciencias Biolóxicas (Inventarios). Seminario de Estudos Galegos 9: 11-55.

Associate Editor: A. Flores Received: 23-IX-2013 Accepted: 3-IV-2015 